\title{
Debt of local authorities in South Africa: Accounting realities leading to ethical, social and political predicaments ${ }^{1}$
}

\section{Dave Lubbe and Cobus Rossouw}

\begin{abstract}
Local authorities in South Africa face ethical, social and political dilemmas in dealing with the reality of the escalating outstanding debt payable to them. The culture of non-payment, and other reasons, have increased the outstanding debts of local authorities for services rendered by them to disturbing levels. However, the continued accounting recognition of further outstanding debt and revenue by local authorities is in reality in conflict with the relevant accounting principles. All stakeholders in the public sector will have to seriously consider whether the overstatement of outstanding debtors of local authorities does not constitute window dressing, unethical and negligent behaviour and in some instances even reckless conduct of affairs to such serious extent that it can no longer be tolerated.
\end{abstract}

Key words: Corporate governance, outstanding debtors, local authorities, ethics, recognition and measurement of debtors and revenue

\section{Introduction}

In general, no part of the public sector plays a larger role in the lives of all citizens of the country on a daily basis than local authorities. The provision of water and electricity, removal of refuse, provision of sewage services and infrastructure such as roads are a number of examples.

Hardly a day goes by that the media do not report on poor service delivery, corruption and other unacceptable events in local authorities in South Africa. Reports on nepotism (Botha, 2007a:4; Naidoo, 2006:1); corruption

Dave Lubbe is professor at the Centre for Accounting at the University of the Free State. He is a Chartered Accountant $(C A(S A))$ and is the first person in South Africa to obtain a doctoral degree in Auditing. He has published the first Afrikaans textbook on Auditing as well as more than hundred and fifty scientific articles and a number of poems. He received the first Ernst and Young Outstanding Accounting Research Award that had been awarded (June 2002) by the Southern African Accounting Association. The Stals Prize for Economic and Management Sciences from the South African Academy for Art and Science was awarded to him during 2007.

Cobus Rossouw is a Chartered Accountant (CA (SA)) and an associate professor in Financial Accounting at the University of the Free State. He holds a master's degree (cum laude) in Financial Accounting. He is currently lecturing Advanced Financial Accounting to aspiring Chartered Accountants at postgraduate level. He is author and co-author of various articles in academic and accounting literature, and author of various chapters in accounting text books.
(Botha, 2007a:4; Viljoen, 2006:4), non-payment of creditors such as water boards (Hamlyn, 2007:7), the unacceptably high outstanding debtors of local authorities coupled to the alarming increase of $47 \%$ in debtors for the nine months since June 2006 (Botha, 2007b:1; Fitzpatrick, 2007:11; Mtshali, 2007:3; Pelser, 2007:15), staff of local authorities who do not make the grade resulting in engaging the very expensive services of consultants to do the work (Botha, 2007a:4; Cull, 2007:11; Van Zyl, 2007:1); political interference when pressure is applied to defaulters of payments for services (Dlodlo, 2007:4; Pelser, 2007:15; Powell, 2007:7) are examples of the dilemma in which local authorities currently find themselves.

All these examples can mostly be viewed as matters of poor corporate governance (see for example the King II Report (IOD, 2002) as the most important source of principles for good corporate governance in South Africa). Corporate governance and good business ethics go hand in hand, and King II also endorses this. On each of the examples of poor corporate governance mentioned above, long ethical debates could be conducted. Ethical issues in many local authorities relate to a) political interference from politicians that prevents officials from collecting service fees in arrears, b) whether consultants should be appointed at great expense to do the work of corrupt or incompetent persons, and c) whether there is a political will to effectively discipline councillors and officials of local authorities who are responsible for these unacceptable ethical circumstances.

Fundamental to most of the problems sketched above are the unacceptably high levels of outstanding debtors of local authorities. In many cases local authorities collect only part of their "income" which results in cash flow problems, an inability to pay their creditors on time, a lack of funds for maintenance and expansion of infrastructure, and poor service delivery. This results in a proverbial vicious circle, which causes many people to be extremely pessimistic about the future of local authorities in South Africa.

In this article the focus is on the non-payment of amounts owed to local authorities and the overstatement of recoverable outstanding debt, with special emphasis on the accounting recognition of debtors and revenue in the annual financial statements of local authorities. The primary purpose of this article is to indicate that sound accounting requirements, against the culture of non-payment, currently leads to various ethical, social and political predicaments within the local authorities 
of South Africa. The focus will be placed mainly on the accounting principles of the recognition of debtors and revenue in cases of a culture of non-payment (partial payment or even no payment) for services rendered. These accounting realities will be discussed against the backdrop of the notion of stewardship and accountability. For the purposes of achieving the goal of this article, the focus is on local authorities in South Africa. Other government and semi-government institutions such as water boards (see Kruger, 2005a:1; Kruger, 2005b:4) and institutions providing electricity and other services and who are heavily burdened by the problem of nonpayment for their services rendered, may also experience similar problems.

This article commences with a brief overview of the outstanding debtors of local authorities in South Africa from an ethical, social and political perspective. This is followed by a discussion of the accounting requirements for the recognition of debtors and revenue, and it simultaneously indicates how the culture of non-payment (and the resultant overstatement of outstanding debtors) and the accounting principles of recognition of debtors and revenue could lead to serious misrepresentations in the annual financial statements of certain local authorities. Finally, a summary is provided, as well as an indication of the problems this possible misrepresentation could cause for different role players.

\section{Outstanding debts to local authorities in South Africa - an overview of the ethical, social and political dilemmas}

\section{Introduction and background}

Traditionally, in many parts of the world, the public (governmental) sector found itself in a field where financial disclosure and management principles, credit grading, were far "removed" from principles as applied in the private sector. The globalisation of the world, the dramatic shock liquidations such as that of Enron and many other companies over the last few years, the establishment of corporate governance principles in the South African public sector by legislation such as the Public Finance Management Act, 1999 (Act 1 of 1999) and the Municipal Finance Management Act, 2003 (Act 56 of 2003), rapidly resulted in specific pressure and challenges for this sector. Add to this international phenomena that pressurised the public sector to be increasingly accountable: a) legislation such as the Sarbanes-Oxley Act (of 2002) (compare Lander, 2004; Whittington \& Pany, 2004:73-74), which followed events such as the Enron scandal in the USA, b) internal accounting control measures and financial management principles traditionally only applicable to the private sector, and c) considerable pressure to expedite the so-called harmonisation of international accounting standards (GAAP).

In addition, the new young democracy in South Africa - which included aspects such as transformation and affirmative action - caused many experts to leave the public service, and their places were often taken by persons with inadequate expertise, training and experience. The new government in South Africa also had to provide services to previously disadvantaged communities as rapidly as possible, and should continue to do so. Prior to the new political dispensation in South Africa, these communities were often instructed by certain political leaders, and even intimidated, to withhold payment for services such as water and electricity. The same leaders are currently appealing to their communities to terminate the culture of nonpayment they have been following for many years, and to now pay for such services (see for instance Lubbe \& Rossouw, 2005a). However, these leaders, as well as other political leaders, often have little credibility in the eyes of these communities due to the 180-degree turnaround they had to make since the anti-Apartheid struggle era. This could also be one of the reasons why the so-called Masakhane project (aimed at creating a culture of payment), which was launched with great expectations during the nineties, was such a dismal failure (see for instance Citizen Reporter, 2000; Lubbe \& Vorster, 2000; Political Correspondent, 1998 in this regard).

The government's policy of providing certain basic services free of charge to the poor also contains the seeds of possible corruption and other practical problems as far as the payment of such services are concerned (see for instance Maqhina, 2005:3). Although there is a "policy" (see for instance the Indigence Illustrative Policy of the Local Government Finance Best Practice Manual (SALGA/ IMFO, 2004a), which is used to define who is poor and to identify the services such persons are entitled to, it remains difficult to practically and objectively determine who is truly poor, and - for various reasons - this process is also very difficult to administrate. Communities often also argue that, "if others are receiving services free of charge, I must also get them for free", or "we are all poor, and why should I pay while my neighbour is getting the services for free?" (see also Sepotokele, 2004:3; Van der Merwe, 2005:4).

In addition to the above-mentioned, elements of theft and thuggery are also often present, e.g. the theft of electrical cables and illegal electricity connections. Situations have arisen where, within a short time after defaulters have had their illegal electricity connections disconnected, these have simply been reconnected and municipal officers have been unable to prevent this. They even received death threats when they attempted to disconnect the illegal reconnections again (see Ryan, 2004:25). 
Lack of political will

In addition, it is often debatable whether politicians really have the will to take strong action against defaulters not paying for services. Politicians often take decisions to ensure popularity and re-election at the cost of the financial sustainability of the entity. There are also cases where a control body, such as the council of a local authority, formulated a debt-collection policy (e.g. the Local Government Finance Best Practice Manual (SALGA/IMFO, 2004b)). However, as soon as officers had to enforce this policy by (e.g. disconnecting electricity supply), councillors intervened, in the interests of their popularity, and prevented management from applying the policy in their wards. This intervention and violation of good corporate governance principles, together with yielding to political pressure, usually renders the debt-collection policy superfluous. As early as the late nineties already, one of the most important reasons for the increasing amounts owed to local authorities was the fact that "councillors lack the political will to enforce credit control measures and political interference prevented many accounting officers from doing their jobs ...(a)ccounting officers needed strong political support from ministers and MECs ..." (in Dlamini, 1997:3). (See also Dlodlo, 2007:4; Louw, 1995; Pelser, 2007:15; Powell, 2007:7).

In documents regarding good corporate governance, it is emphasised that an institution's board and management set the example for subordinates. In practice, however, it is often found that councillors not only display a lack of political will to take strong measures against defaulters, but are often also guilty of the same misdemeanour, since they themselves owe large amounts to the local authorities where they serve as councillors. It is also ironic that there are even cases of institutions such as provincial and national government departments that owe large amounts which have been outstanding for long periods, for municipal services (see Blaauw, 2004:5; Dlodlo, 2006:2; Dlodlo, 2007:4; Malefane, 2005:2; Maqhina \& Carlisle, 2003:1; Maqhina, 2003:7; Zuzile, 2003:1).

These reasons for non-payment of services and the accompanying increase in the debtors of local authorities, as well as numerous other political, popular, short-term and inconsistent decisions, contributed to a dramatic increase in the outstanding debt of local authorities and certain other government and semi-government institutions. This can be summarised as the existence and growth of a culture of non-payment among a large section of the South African public.

\section{Outstanding debt and financial reporting - an overview}

The management of an institution and its auditors (even in the private sector) are often at loggerheads about writing off uncollectible debt and provisions thereof.
The reason for this is that such provisions are based on estimates and future market forces. These always involve some measure of subjectivity.

The management of an institution desires the annual financial statements to create as good an impression as possible, while the auditors, particularly in view of the risks involved in expressing an incorrect auditing opinion, want to follow a more conservative (realistic) approach. The accounting entries at smaller local authorities in particular, are often of such a nature that proper age analyses of debts cannot be conducted, which produces inadequate and incomplete information for the realistic determination of provisions for doubtful debts. This leads to unrealistic profits or lower than actual losses, which have a negative effect on the problems regarding write-offs of uncollectible debts, and particularly on provisions in this regard. Furthermore, it must also be remembered that the top management of certain local authorities are presently appointed on a contractual basis, as is often the case in the private sector, and that a certain portion of their income is based on performance (see also Kwon Hoo, 2005:4; The Local Government Municipal Systems Act, 2000, Act 32 of 2000). This could also be a reason why such managements will avoid adequate write-offs for uncollectible debts, since this will have a direct impact on the profit of the local authority, and will thus directly affect the person's performance based remuneration.

The culture of non-payment and outstanding debtors of local authorities

The culture of non-payment for services rendered by local authorities has, in fact, developed since the late 1980's. In this section of the article, a general overview and emphasis of the severity of this tendency is provided.

The debt burden, and in particular the increase in amounts owed to local authorities for services rendered (e.g. water, electricity, rates and taxes), is reaching serious proportions in South Africa. As early as 1997 it was strongly recommended, in terms of the guidelines of the International Monetary Fund, that the debts of local authorities should be excluded from the provision of granting credit to the private sector, since the debt burden of local authorities seriously disturbs the credit rating figures (Schutte, 1997:16). This, in turn, has a detrimental effect on the entire South African economy. In support of this argument, it was stated that the debt burden of local authorities had increased by an astronomical 193\% from September 1996 until the corresponding month in 1997 (Raboroko, 1999:3). (See also Alfreds, 1998; Blaauw, 2004; Muller, 1997; Pretorius, 2004; Ryan, 2005; Sekano, 2003). According to the Free State Province's Department of Finance (2005), more than $80 \%$ of the total outstanding debts in this province are already older than 60 days. 
The problems associated with the inadequate provision for dealing with uncollectible debts by local authorities are further evident if the reasons for qualified auditor's reports of such authorities are evaluated. In the case of the twenty largest local authorities in South Africa, the auditors' reports of all twenty were qualified reports on the basis of inadequate provision for uncollectible debts (compare National Assembly, 2005, annexure B; also compare Auditor-General, 2004). This state of affairs is certainly cause for serious concern, and clearly displays the dilemma within local authorities regarding the recognition of revenue and debtors.

Even the so-called Masakhane project which was launched with a view to, inter alia, improving the payment of services, and on which more than R25 million had already been spent by the middle of 1997 , did not have the desired effect at all. Du Toit (1998:2) mentions that the project is now finally on the rocks (see also Muller, 1997; Ngwema, 1996; and Imbono, 1998, for statistics on the so-called "project viability" for local authorities).

Du Toit (1998:2) states that it is estimated that up to a third of the local authorities in the country could already be technically bankrupt. He compares the situation to that in Mexico, where the financial collapse of local authorities bogged the government down in debt (see also Kroukamp, 1995). Research by Alfreds (1998) revealed that 171 local authorities were facing bankruptcy in 1998. This figure does not include local authorities in the KwaZulu-Natal and Northern Provinces. Motale (2003) points out that outstanding debtors of local authorities have increased by an astronomical 1350 \% from 1995 until 2002.

The devastating snowball effect of the outstanding debtors leads to the overstatement of recoverable debtors in the financial statements of local authorities. This results in many local authorities charging for services that soon prove to be uncollectible, if they had not already been uncollectible from the start, and charging interest on such amounts - which will probably also be uncollectible - year after year. Consequently, the annual financial statements of such local authorities indicate that unrealistic profits are being made (or indicate lower than actual losses) on certain services, which of course paints an inaccurate picture. Such profits quite often promote the culture of non-payment even further and, to a great extent, mask the actual critical state of the local authorities' financial position. In addition, this perceived profit shifts the focus away from the cashflow actual problem many have to contend with. This can be ascribed to the fact that profit (out of ignorance, wilfulness or due to a hidden political agenda [DiPiazza $\&$ Eccles, 2002]) is regarded as equal to cash, or presented as good results.

These problems are reflected in the research findings of the South African Institute for Race Relations (Eybers, 1998:11), which indicate that the largest proportion of local authorities' overdue debt of R8,9 billion (in 1998) consists of old debt that can never be recovered (see also Russel, 1998:2).

\section{The "new" legislation for local authorities: an overview}

The "new" financial legislation for the public sector in South Africa is rated very highly. Certain acts, e.g. the Municipal Finance Management Act, are referred to as benchmark legislation for the public sector worldwide. However, the execution and application of this act in South Africa often leave much to be desired. It was shown earlier that overstatement of debtors by local authorities is assuming crisis proportions. The reasons for this were also pointed out (e.g. political interference by certain councillors, political and personal own gain). Such unacceptable conduct is, to a lesser or greater extent, in contravention of several stipulations of the above-mentioned act. The following are some of the sections of the Municipal Finance Management Act that are possibly contravened or that are not implemented in situations as discussed here: Sections 13, 16, 17, 22, 24, $32,45,46,53,54,55,61,62,63,64,65,68,70,71,72$, 87, 94, 95, 96, 97, 100, 101,102,103, 104, 133, 171, 172. It should also be pointed out that certain provisions of other acts, such as the Systems Act, could also be added to this list.

In conclusion: The crisis situation in which many local authorities in South Africa find themselves is aptly described by a mayor of such a local authority. He stated that the debt collection had declined from "bad to worse $\ldots$ and that the debt book had increased at an unprecedented rate". He also mentions that critical staff shortages could consequently not be addressed and that, if "this situation persists, we are doomed" (Naki, 2005:5).

In the discussion thus far it was indicated that the outstanding debts of local authorities in South Africa are reaching alarming proportions. The next section deals with the extent to which the preceding and the accounting principles for the recognition of debtors and revenue by local authorities in South Africa are irreconcilable.

\section{Accounting realities for the recognition of debtors and revenue by local authorities}

The purpose of this article is not to discuss all the detailed accounting principles for the recognition and measurement of debtors and revenue, but to interpret some of these principles in terms of the ethical, social and political issues indicated above. The general accounting principles for the recognition of debtors and revenue in broad terms will subsequently be identified on the basis of a) the accounting standards specifically applicable to local authorities and b) 
applicable International Financial Reporting Standards (IFRSs) that represent South African Standards on Generally Accepted Accounting Practice (GAAP). As stated earlier the recognition of debtors and revenue by local authorities is problematic due to the consistent and rapid increase in the outstanding debtors of many local authorities. The culture of non-payment and the political agendas of local authorities create unique problems in the recognition and measurement of debtors and provision for doubtful debt (impairment of debtors), as well as the associated revenue.

As focus area of this article the accounting realities relating to debt and revenue indicated below, relate specifically to the stewardship assumed by the management of local authorities. Stewardship basically implies that an agent (municipal management in this context) is assumed to safeguard the resources of the principal (the public in this context) (Riahi-Belkaoui, 2000:62). The notion of stewardship currently manifests itself in concepts such as corporate governance, ethics and accountability (Brenkert, 2004; Carroll \& Buchholtz, 2006; Keasey, Thompson \& Wright, 2005:23-24; Solomon \& Solomon, 2004:15, 23; Vorster et al., 2006:16), as discussed in the first section of the article.

In the private sector, the continued provision of goods and services to purchasers who are not paying would be in conflict with the stewardship the management accepts with regard to the shareholders (refer to paragraph 14 of the Framework for the Preparation and Presentation of Financial Statements - IASB, 2006). This principle of stewardship is also contained in the public sector's equivalent, namely GRAP 0: Framework for the Preparation and Presentation of Financial Statements, paragraph 15, which stipulates that "(s)tewardship plays an important role in the use of financial statements of the public sector. Accountability for the use of public funds and the safekeeping of the entity's resources is of paramount interest ... The assessment of stewardship will also indicate whether fiscal policies are sustainable over the long term ... Financial reporting plays a major role in fulfilling the duty to be publicly accountable for the collection of taxation and other revenue and its use in the rendering of public services." From the above discussion on the alarming increase in the outstanding debt of local authorities it is clear that local authorities lack the stewardship assumed. This casts doubt on their ethics. However, since politics and social pressure also play a role in the case of local authorities, the provision of water and electricity to communities involves much more than just complying with stewardship.

In his description of "The Ethics of Financial Reporting" Enderle (in Brenkert, 2004:88-91) states that truthfulness of and trust in the financial reports, amongst others, capture the core ethical issues of financial reporting. "The numbers are expected to be correct, accurate, comprehensive, objective, and understandable and to adequately reflect real processes and states of affairs (balance sheet) of the reporting organisation... according to appropriate rules of reporting... A modern term for such truthfulness is transparency, meaning the reporting is 'transparent' to the underlying 'reality'; it does not hide substantial parts of this reality or deceive those who receive and need the reports." (Enderle in Brenkert, 2004:88-91).

In the section above, it was stated that the auditors' reports of the twenty largest local authorities in South Africa were all qualified reports on the basis of inadequate provision for uncollectible debts. This is a clear indication of a lack of core ethical accountability of financial reporting in this sector. In the following sections the accounting realities will be contrasted to the social and political aspects related to municipal debt, and the question whether local authorities in South Africa fulfil their stewardship function in a transparent and ethical manner is addressed.

\section{Accounting recognition of debtors}

The International Financial Reporting Standards mainly follow a balance sheet approach in financial reporting. The accounting realities of the balance sheet items, namely outstanding debt will therefore be discussed first. By definition, since debtors constitute a contractual right of the seller to receive cash, debtors represent a financial asset (see IAS 32 (AC 125) Financial Instruments: Disclosure and Presentation - IASB, 2006:par. 11). To date, no GAMAP standard has been issued regarding the recognition and measurement of financial instruments, which include debtors, and the International Financial Reporting Standards on financial instruments are considered to be appropriate (Lubbe \& Rossouw, 2005b:790). IAS 39 (AC 133) contains detailed principles for the recognition and measurement of financial assets, including debtors. Simply put, debtors are measured at the initial amount charged, minus repayments, plus interest charged, minus impairments for uncollectibility.

Naturally, the recognition of a debtor must comply with the basic definition of an asset. The GRAP 0 Framework, (paragraph 66(a), defines an asset as a resource controlled by the entity as a result of past events and from which future economic benefits or service potential is expected to flow to the entity. The common characteristic of assets is indeed that they represent future economic benefits that will result in the inflow of cash (Vorster et al., 2006:26). It is the probability of expected inflow of economic benefits that, in view of the high outstanding debt of local authorities and the culture of non-payment, is of great importance for this article, as doubt exists whether the debtors will actually pay the outstanding amounts. 
Accounting provision for doubtful debt (impairment of debtors)

The previous paragraph dealt with the recognition of debtors. In terms of GAMAP 9.17,28,35, (as well as IAS 18 (AC 111)), a so-called provision for doubtful debt is only created if, after the revenue has already been recognised correctly in terms of GAAP, doubt arises about the collectibility of the amount that has already been recognised in revenue (also see Ernst\&Young, 2004:1476).

With regard to the provision for doubtful debt it is, once again, the probability of economic benefits that is decisive. It is stated in GRAP 0 Framework, (paragraph 114), that the assessment of the probability of economic benefits must be based on evidence available at the time the financial statements are drawn up. It is further indicated that some degree of non-payment of a large population of debtors is probable under normal circumstances, and that an expense must be recognised in order to reflect the decline in expected economic benefits.

In accordance with the principles of IAS 39 (AC 133), a loss due to an impairment loss must be recognised if there is objective evidence of impairment (for example, the non-payment of a debtor). An impairment loss should, therefore, be recognised so that the debtors are measured at the present value of the amount the local authority actually expects to receive (see IAS 39 (AC 133).63). In light of the culture of non-payment, it is evident that the present value of the expected cash flow (repayment) will probably be less than it would be if debtors were paying their outstanding debt. It is clear that the measurement of the debtor should also take the uncollectibility of the debt into account, while the contrary is evident in light of the qualified audit reports of the twenty largest local authorities referred to earlier.

\section{Accounting recognition of revenue}

The debtor and revenue are recognised simultaneously, and revenue cannot be recognised if the definition and recognition criteria for an asset are not met (Alfredson et al., 2007:138; Sowden-Service, 2007:12). Lubbe and Rossouw (2005b:787-789) argued that it is not only with regards to the recognition of debtors that local authorities contrive the accounting standards, but also with the recognition of revenue. In terms of GRAP 0 Framework for the Preparation and Presentation of Financial Statements (ASB, 2004 - GRAP 0:par.12-17) users of financial statements of local authorities need information about the performance of the local authority. Performance is the ability of an entity to earn a surplus on the resources that have been invested in it (Alfredson et al., 2007:134). A local authority, therefore, sells goods and services (water, electricity and other services) to the public. In order to assess performance users thus need information about the income and expenses. Revenue is usually the single largest item in financial statements, and users assess the trends, growth and components of an entity's revenue as an indicator of the entity's past performance and future prospects (Alfredson et al., 2007:134-135)

Revenue recognition remains a high-risk area for misrepresentation, whether it amounts to fraud, is an attempt to make the financial statements appear more positive, or simply occurs due to ignorance. Although the recognition of revenue is actually very basic, it is nevertheless, a complex matter to determine when revenue may be recognised and at what amount (see also DiPiazza \& Eccles, 2002:47; Ernst \& Young, 2004:14531455; Riahi-Belkaoui, 2000:385).

The accounting recognition of revenue for the private sector is prescribed by IAS 18 (AC 111) Revenue (IASB 2006). Revenue recognition for local authorities is prescribed by GAMAP 9 Revenue (ASB, 2004(a)). In terms of GAMAP 9, revenue is defined as "... the gross inflow of economic benefits or service potential during the period when those inflows will lead to increases in net assets..." (GAMAP 9.7). In view of the aim of this research, the definition of revenue has specific implications for local authorities. It is important to note that revenue can only be recognised as such if it leads to an increase in net assets. In light of the escalating outstanding debt payable to local authorities some doubt exists whether the continued supply of water and electricity to nonpayers would indeed lead to and increase in net assets (funds) (Lubbe \& Rossouw, 2005b:787-792).

The basic components of revenue of local authorities are mainly the sale of goods, particularly in the form of electricity and water provided (sold) to the public and the rendering of refuse removal services and sanitation (the revenue of which coincides with the levying of rates). These are addressed specifically in GAMAP 9. Local authorities may only recognise revenue when detailed criteria (see GAMAP 9.24, 29) have been satisfied. The criterion for recognition of revenue - for the purposes of this article - that creates the most problems from an accounting perspective is the probability that economic benefits need to flow to the local authority. This implies that the recipient of the electricity and water must pay the local authority for it.

On the basis of the definition of revenue above, as well as the above-mentioned criteria for recognition, local authorities may only recognise revenue when, and if, it is probable that economic benefits or service potential will flow to the local authority (also compare Pretorius et al., 2006:131), which complement the recognition criteria for debtors as discussed above. This implies that local authorities must determine beforehand whether the individual or institution to which water or electricity is provided will be able to pay for it (has the ability to pay). In view of the culture of non-payment discussed earlier, the local authority must not only determine whether the individual or institution will be able to pay, but also whether they want to pay (are willing 
to pay). If any of these requirements are not met, the revenue from the supply of water or electricity cannot be recognised as such (also refer to GAMAP 9.28). The practical implication of this is that local authorities must evaluate and assess the ability and willingness to pay of the individual or institution to which water or electricity is provided beforehand. Lubbe and Rossouw (2005b:787789) therefore stated that revenue that is recognised in a case of non-payment by debtors by certain local authorities is in conflict with the accounting principles, since the criteria of probable economic benefits that will flow to the local authority are not being met in the continued provision of goods and services to purchasers who are not paying in any case.

\section{Implications of the accounting realities}

It was indicated above that many local authorities in South Africa are heavily burdened by a culture of non-payment. These sections of the article provided an overview of the recognition of debtors and revenue of local authorities. It is clear that there is sufficient reason to reach the conclusion that certain debtors and revenue is recognised by certain local authorities in cases where accounting requirements for the recognition and measurement are not met. It is also clear that, in the case of certain local authorities, provision for doubtful debts is not always made in accordance with accounting standards. This reality threatens transparency. Enderle (in Brenkert, 2004:88-91) identified these phenomena as some of the core ethical issues of financial reporting.

\section{Conclusion}

In general, the amounts owed to local authorities in South Africa have reached alarming proportions and have farreaching consequences, not only for the local authorities concerned, but for the provincial and national spheres of government as well. In the final analysis this state of affairs affects the well-being of every South African citizen. Numerous reasons are advanced for this, but most of these reasons are unacceptable from a corporate governance and ethical point of view. Local authorities councillors are responsible, among others, to fulfil their stewardship function and to ensure that the annual financial statements of the authorities comply with existing relevant national and international accounting standards. In addition, the accounting disclosure of certain local authorities is often distorted and presents financial information that impedes sound financial management, or even make it impossible.

The often intentional failure to implement provisions (due to a lack of expertise, political gain, reckless negligence, or for whatever reason) as well as the failure of the authorities to act against local authorities guilty of contraventions, bears testimony of inexcusable unethical conduct that cannot be tolerated in any country. (In this respect also compare Section 424 of the Companies Act that deals with the reckless running of a company in insolvency circumstances by the board of directors of such company.)

The possibility that many local authorities in South Africa will soon be unable to provide the necessary services, is becoming an increasingly greater reality. The culture of non-payment, and other reasons, has increased the outstanding debts of local authorities and other public sector institutions for services rendered by them to disturbing levels. The accounting and control measures within local authorities with regard to outstanding debts, and in particular to the collection of these debts together with political interference by politicians, often leave much to be desired. If the preceding, as well as principles of Generally Accepted Accounting Practice (GAAP, GAMAP and GRAP) are taken into account, it is clear that there is more than enough reason for concern that the financial statements of many local authorities in South Africa do not comply with GAAP, and for the purposes of this article, the incorrect recognition and measurement of revenue and debtors. Local authorities, and the public sector as a whole, as well as other influential role players like the AuditorGeneral, politicians, audit firms involved in public sector audit work, the legal profession and prosecuting authorities, will have to be acutely cognisant of the fact that the overstatement of outstanding debtors of local authorities may constitute window dressing, unethical and negligent behaviour, and in some instances even reckless conduct of affairs to the extent that it can no longer be tolerated.

\section{References}

Alfreds, L. (1998). 100 towns are facing bankruptcy and can't pay staff. The Star 10 March:1.

Alfredson, K., Leo, K., Picker, R., Pacter, P., Radford, J. \& Wise, V. (2007). Applying International Financial Reporting Standards. Milton, Australia: Wiley.

Accounting Standards Board (ASB). (2004a). Standards of Generally Accepted Municipal Accounting Practice. http://www.asb.co.za/backoffice/contentdocs/doc_ 552004113559_11.pdf (23 June 2005).

Accounting Standards Board (ASB). (2004b). Framework for the preparation and presentation of financial statements (GRAP 0). http://www.asb.co.za/backoffice/contentdocs/ doc_18200411856_11.pdf (23 June 2005).

Auditor-General (2004). General Report of the Auditor-General on the audit outcomes of local government for the financial year ended 30 June 2003. Pretoria: Government Printer.

Blaauw, D. (2004). Uitstaande munisipale skuld in VS meer as R3 miljard. Volksblad 29 October: 5.

Botha, E. (2007a). Act fast on mayor, MEC urged. Daily Dispatch. 29 January: 1.

Botha, E. (2007b). Mnquma residents in red to tune of R200m. Daily Dispatch. 29 March: 4. 
Brenkert, G. (ed) 2004. Corporate integrity and accountability. Thousand Oakes, CA: Sage.

Carroll, A.B. \& Buchholtz, A. K. (2006). Business \& society: Ethics and stakeholder Management. Thomson SouthWestern.

Citizen Reporter. (2000). MEC hit on Masakhane. The Citizen 15 May: 7.

DiPiazza, S.A. \& Eccles, R.G. (2002). Building public trust: The future of corporate reporting. New York: Wiley.

Department of Finance - Free State (Local Government Directorate). (2005). Monthly report on the state of local government finance and related matters pertaining to district \& local municipalities in the Free State for the quarter ending at 31 March 2005: 74.

Dlamini, J. (1997). Local government debt climbs to R6,5bn. Business Day, (1997), 29 April:3.

Dlodlo, C. 2006. VS-departemente skuld miljoene. Volksblad 23 November: 2.

Dlodlo, C. (2007). Los amptenare om skuld in te vorder. Volksblad 5 March 2007: 4.

Du Toit, Z. B. (1998). Stadsrade stuur af op geldramp. Rapport, 3 May:2.

Ernst\&Young. (2004). International GAAP 2005. London: LexisNexis.

Eybers, J. (1998). Dié gemeenskappe sal nie hul diensgeld betaal nie. Beeld, 20 November: 11.

Fitzpatrick, M. (2007). Waar daar nie 'n wil is. Beeld, 9 Januarie: 11.

Hamlyn, Michael. (2007). Municipalities failing to pay R794m debt to water boards. Johannesburg Star, March 20:7

Institute of Directors (IOD). (2002). The King report on Corporate Governance. Johannesburg: IOD.

International Accounting Standards Board (IASB). (2006). International Financial Reporting Standards (IFRSs) including International Accounting Standards (IASs) and Interpretations as at 30 November 2006. London: IASB.

Keasey, K., Thompson, S. \& Wright, M. (2005). Corporate governance - Accountability, enterprise and international comparisons. London: Wiley.

Kroukamp, H. (1995). The culture of non-payment of services as a constraint in financial policy management for local authorities in South Africa. SAIPA, 30(3) 189202.

Kruger, E. (2005a). Munisipaliteit skuld glo R12m. vir water. Volksblad, 13 January: 1.

Kruger, E. (2005b). Kopanong-voorneme oor water lagwekkend - DA. Volksblad, 25 January: 4.

Kwon Hoo, S. (2005). New city manager sets his sights on debt collection. Diamond Fields Advertiser. 4 January: 4.

Lander, G.P. (2004). What is Sarbanes-Oxley? New York: McGraw-Hill.

Louw, R. (1995). Non-payment by township residents for municipal services is emerging as major local elections issues. South Africa Report, 13(41):1-3.

Lubbe, D.S. \& Rossouw, C. (2005a). Accounting for a culture of non-payment. Accountancy SA, December 21-25.

Lubbe, D.S. \& Rossouw, C. (2005b). The recognition of revenue and the escalating debtors of munisipalities in South Africa: Political and social dilemmas vs. Accounting realities. Journal of Public Administration, 40 (4): 780 - 795.
Lubbe, D.S. \& Vorster, Q. (2000). Enkele gedagtes oor die uitstaande skulde van plaaslike owerhede. TCW, 36 (3 \& 4) 101-113.

Malefane, M. (2005). Councillors owe nearly R1,4 in rates, charges. Johannesburg Star, 3 February 2005: 2.

Maqhina, M. (2005). Ratepayers owe close to R1bn to four councils. Daily Dispatch, 22 February: 3.

Maqhina, M. (2003). Govt debt to munisipalities slated. Daily Dispatch, 11 April : 7.

Maqhina, M \& Carlisie, A. (2003). Bisho owes council R25m for rates, services. Daily Dispatch, 25 January: 1.

Motale, S. (2003). Govt to aid debt-hit councils. Citizen, 13 March: 8.

Mtshali Thokozani. (2007). Munisipalities hit by R28bn debt. Star. 5 March: 3.

Muller, H. (1997). Payment of services: revenue collection systems. Local Government Digest 16(12):30-31.

Naidoo, N. (2006). Cashing in on council debt. Witness, 13 September. 1.

Naki, E. (2005). Mayor calls for stern action against defaulters. Daily Dispatch, 28 February:5.

National Assembly. (2005). Written reply to internal question number 648.

Ngwema, S. (1996). No consultation - no cash flow. Democracy in Action, 10(1):8-9.

Pelser, W. (2007). Skokkende skuld lei tot swak diens. Beeld, 5 March 2007:15.

Powell, A. (2007). Cutting off non-payers victimises the poor - ANC. Cape Time,. 16 March 2007.:7.

Political correspondent. (1998). New broom to boost the Masakhane campaign. Daily News, 5 February; 6.

Pretorius, D., Venter, E., Von Well, R. \& Wingard, C. 2006. GAAP Handbook 2007. Durban: LexisNexis Butterworths.

Pretorius, L. (2004). Verbruikers in VS skuld miljarde - Munisipaliteite in rooi. Volksblad ,17 March: 6.

Raboroko, J. (1999). Local authorities to get tough on rent, service defaulters. Sowetan, 5 May:3.

Riahi-Belkaoui, A. (2000). Accounting theory. New York: Thompson Learning.

Ryan, C. (2004). Delinquent debt tops R40bn. Weekly Mail and Guardian, 13 May: 25.

Republic of South Africa. (2000). Local Government Municipal Systems Act (Act 32 of 2000).

Republic of South Africa. (1999). Public Finance Management Act (Act 1 of 1999)

Republic of South Africa. (2003). Municipal Finance Management Act (Act 56 of 2003).

Russel, C. (1998). End in sight for municipal debt. The Star, 2 July:2.

South African Local Government Association (SALGA)/ Institute of Municipal Finance Officers (IMFO). (2004a). Local Government Finance Best Practice Manual: Indigency illustrative policy. http://www.imfo.co.za/manual.htm (10 May 2005).

South African Local Government Association (SALGA)/ Institute of Municipal Finance Officers (IMFO). (2004b). Local Government Finance Best Practice Manual: Credit control. http://www.imfo.co.za/manual.htm (10 May 2005).

SAPA. (1997). Local government finances alarm AuditorGeneral. The Citizen, 27 March:4. 
Schutte, H. (1997). Plaaslike owerhede se skuldlas groei. Die Burger, 14 November:16.

Sekano, P. (2003). Council takes legal action against owners of flats. City Press, 19 January: 10.

Sepotokele, T. (2004). Councils face different problems. Star, 12 November: 3.

Solomon, J. \& Solomon, A. (2004). Corporate governance and accountability. West Sussex: Wiley.

Sowden-Service, C. (2007). Gripping GAAP. Durban: LexisNexis Butterworths.

Van der Merwe, H. (2005). Veranderinge hier beloof. Volksblad, 4 January: 4.

Van Zyl, Roux, (2007). ECDC calls on outside help for R500m "bad debts". Daily Dispatch, 2007, March 19: 1

Versluis, J. 2005. Munisipale finansies 'benard'. Volksblad, 2 August: 1

Viljoen, B. 2006. Mpumalanga se DG skuld glo duidende. Beeld, 7 Desember: 4.
Vorster, Q., Koornhof, C., Oberholster, J., Koppeschaar, Z. \& Venter, E. 2006. Descriptive accounting IFRS focus. Durban: LexisNexis Butterworths.

Whittington, O.R. \& Pany, K. 2004. Principles of auditing and other assurance services. New York: McGraw Hill Irwin.

Zuzile, M. 2003. Council cuts put legislature in dark. Daily Dispatch, 16 April: 1.

(Endnotes)

1 This article is an amended version of a paper that the authors presented during the $6^{\text {th }}$ Annual conference of BEN-Africa, 26 - 28 July 2006 , Bellville, South Africa. 
Reproduced with permission of the copyright owner. Further reproduction prohibited without permission. 